\title{
Biometric Indexes in the Early Selection of Potassium Use Efficient Sugarcane Genotypes
}

\author{
Juan Camilo Rey Sandoval ${ }^{1}$, Evandro Marcos Biesdorf ${ }^{1}$, Angélica Fátima de Barros ${ }^{1}$, \\ Márcio Henrique Pereira Barbosa ${ }^{1}$, Luis Cláudio Inácio da Silveira ${ }^{1} \&$ Leonardo Duarte Pimentel $^{1}$ \\ ${ }^{1}$ Federal University of Viçosa, Viçosa, Minas Gerais, Brazil \\ Correspondence: Juan Camilo Rey Sandoval, Federal University of Viçosa, Viçosa, MG, Brazil. Tel: \\ 57-322-824-5726. E-mail: juan.camilo.reysandoval@hotmail.com
}

Received: May 19, 2020

doi:10.5539/jas.v12n8p202
Accepted: June 21, $2020 \quad$ Online Published: July 15, 2020

URL: https://doi.org/10.5539/jas.v12n8p202

The research is financed by Brazilian National Council for Scientific and Technological Development (CNPq) and Federal University of Viçosa (UFV).

\begin{abstract}
Brazil is the world's largest producer of sugarcane (Saccharum officinarum). In this context, in addition to the already extensive areas occupied with sugarcane crops, new areas, characterized as having low natural soil fertility, have been incorporated into the production system, showing that the new sugarcane genotypes that are efficient in the use of mineral nutrients in the soil they must be selected for use in these areas. Thus, the objective with this work was to evaluate the feasibility of using biometric indexes in the early selection of potassium (K) use efficient sugarcane genotypes. For this, four sugarcane genotypes were submitted to five doses of K, evaluating the possibility of selection during the initial phases of the crop (at 5,8 and 14 months of age). The RB92579 genotype was the most efficient in the use of K for stem dry matter, showing that it is possible to select efficient genotypes in the use of $\mathrm{K}$ using the stem dry mass or efficiency in the use of $\mathrm{K}$ as indexes already at 8 months after planting in sugarcane, but provided that they are tested under conditions of low $\mathrm{K}$ availability in the soil, that is, without adding fertilizers to the soil.
\end{abstract}

Keywords: plant breeding, mineral nutrition, Saccharum officinarum

\section{Introduction}

Sugarcane (Saccharum officinarum) is grown in all regions of Brazil, which is the world's largest producer (Companhia Nacional de Abastecimento do Brasil, 2020). According to CONAB (2020), about $72 \%$ of Brazilian sugarcane production is concentrated in the states of São Paulo, Goiás and Minas Gerais. In other words, places that present soils with low natural fertility ("cerrado" regions) and with large volumes of rainfall throughout the year, being, therefore, places that require large amounts of investments in soil fertilization (Figure 1). 


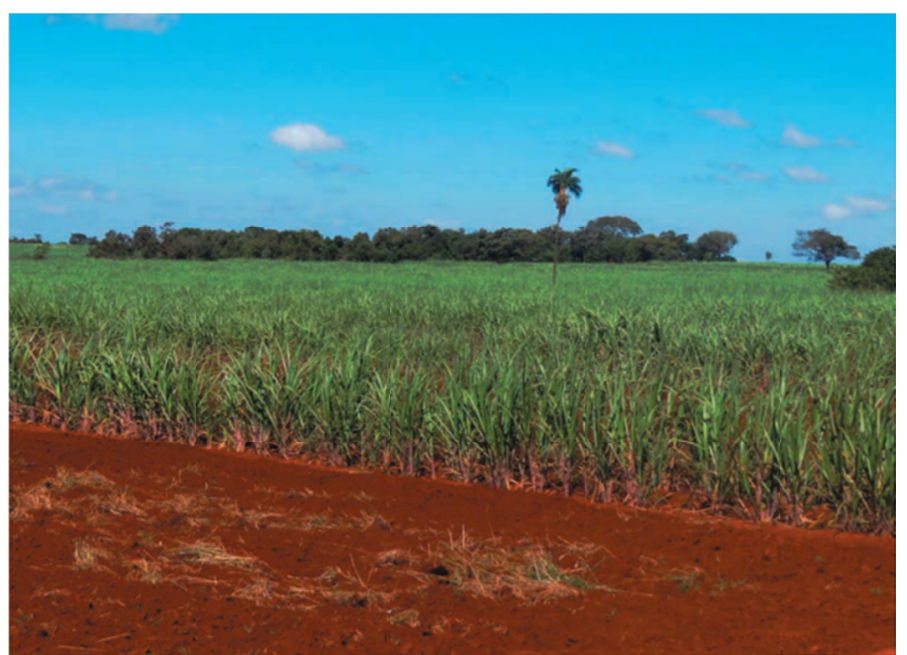

Figure 1. Sugarcane landscape. Municipality of Itumbiara, Brazilian State of Goiás. Fieldwork: Marcelo Luiz Delizio Araújo, 2017

Note. Image obtained from The Geography of Sugarcane (Instituto Brasileiro de Geografia e Estatística, 2017).

However, although Brazil is the world's largest producer of sugarcane, the average productivity of sugarcane fields is low, $75 \mathrm{t} \mathrm{ha}^{-1}$, according to estimative data from the 2020/2021 harvest (CONAB, 2020). This low productivity can be attributed to the fact that many sugarcane fields are in a "cerrado" environment, therefore, in an environment in which high doses of fertilizers are necessary to obtain economically viable production.

CONAB (2020) estimates foresee an annual growth in sugarcane production of at least $18.5 \%$ to supply the world's needs for sugar. In other words, this increase in production could culminate in an increase in the area planted with sugarcane in the "cerrado" regions, whose soils have low natural fertility, high acidity, low cation exchange capacity (CEC), high phosphorus fixation and low contents of exchangeable bases, such as potassium (K) (Tomaz, Silva, Sakiyama, \& Martinez, 2003), revealing the need for genotypes that are efficient in the use of soil mineral resources for their development and production.

The use of sugarcane genotypes efficient in the use of nutrients is indispensable as it is observed that the culture of sugarcane is responsible for approximately $13 \%$ of the total fertilizers consumed annually in Brazil, with a total of 4.4 million tons $(\mathrm{Mt})$, less than the total amount consumed by soybean $(14.5 \mathrm{Mt})$ and corn $(6.1 \mathrm{Mt})$ crops (Associacção Nacional para Difusão de Adubos, 2016).

Potassium $(\mathrm{K})$ is the nutrient applied in greater quantity in Brazilian sugarcane fields. K deficiency in the plant directly affects the productivity of the sugarcane field and can decrease the quality of the harvested product, also influencing the agro-industrial characteristics.

Results indicate that the order of $1.3 \mathrm{~kg}$ of potassium per ton of stem produced. Therefore, considering that Brazil produces, an average of $700 \mathrm{Mt} \mathrm{year}^{-1}$ of sugarcane, an estimated annual consumption of approximately 1.5 Mt of potassium chloride, emphasizing that the $\mathrm{K}$ used in sugarcane crops in Brazil comes from imports (Departamento Nacional de Produção Mineral, 2016), which have been made more expensive by the appreciation of the US dollar in recent years, reducing the profitability of the sugarcane crop and placing Brazil in a position of economic vulnerability with regard to the global sugarcane trade.

The alternative that has been studied in Brazil to overcome these obstacles is the search for more efficient genotypes in the use of mineral nutrients and thus impacting on the reduction of the input of external mining fertilizers in the fields. The efficiency in the use of nutrients can be calculated by the biological utilization coefficient (CUB), which consists of the ratio between the dry matter mass (DM) and the accumulation of nutrients (AN) (Guo, White, Wang, \& Xing, 2018) relating it equally the production.

Therefore, the objective of this work was to analyze the feasibility of using biometric indices in the selection of efficient genotypes in the use of potassium in sugarcane. 


\section{Method}

\subsection{Experimental Conditions and Experimental Design}

The experiment was carried out at the Diogo Alves de Melo Experimental Station, Gleba Aeroporto, belonging to the Plant Science Department of the Federal University of Viçosa (UFV), in Viçosa, MG. The local geographic coordinates are $20^{\circ} 46^{\prime}$ south latitude and $45^{\circ} 52^{\prime}$ west longitude, at an altitude of approximately 650 $\mathrm{m}$.

This study was conducted between June 2015 (winter season) and August 2016. The region's climate is humid subtropical with dry winter and hot summer, according to the Köeppen-Geiger classification (Alvares Stape, Sentelhas, Gonçalves, \& Sparovek, 2013) with an average annual temperature of $21{ }^{\circ} \mathrm{C}$ and an average annual rainfall of $1,200 \mathrm{~mm}$.

The experiment was planted in a dystrophic Red-Yellow Argisol which had the following characteristics in the 0-0.20 m layer: $\mathrm{P}$ (Mehlich-1 Extractor) $=10 \mathrm{mg} \mathrm{dm}{ }^{-3}$; Organic matter $=33.6 \mathrm{~g} \mathrm{dm}^{-3} ; \mathrm{pH}\left(\mathrm{CaCl}_{2}\right)=5.56 ; \mathrm{K}=62$ $\mathrm{mg} \mathrm{dm}{ }^{-3}, \mathrm{Ca}, \mathrm{Mg}, \mathrm{Al}$ and $\mathrm{H}+\mathrm{Al}=4.7 ; 1.4 ; 0$ and $4.1 \mathrm{cmol}_{\mathrm{c}} \mathrm{dm}^{-3}$, respectively and $\mathrm{V} \%=61 \%$.

Planting fertilization with phosphorus (P) was carried out using $112 \mathrm{~kg} \mathrm{ha}^{-1}$ of $\mathrm{P}_{2} \mathrm{O}_{5}$ whose commercial product was single superphosphate $\left(50 \%\right.$ of $\left.\mathrm{P}_{2} \mathrm{O}_{5}\right)$ in all treatments, applied to the bottom of the planting furrow. Potassium fertilization was carried out at planting according to the treatments, the doses were: $0 ; 63 ; 129 ; 195$ and $261 \mathrm{~kg} \mathrm{ha}^{-1}$ of $\mathrm{K}$, in the form of potassium chloride $\left(60 \%\right.$ of $\left.\mathrm{K}_{2} \mathrm{O}\right)$.

The studied sugarcane cultivars were RB987935 with medium-late maturation and RB92579, RB867515 and RB988082, the three with medium maturity, belonging to the Germplasm Bank of the Sugarcane Genetic Improvement Program (PMGCA-UFV/RIDESA).

\subsection{Sampling and Measurements}

The experimental design used was randomized blocks, with four replications, with plots consisting of five lines (grooves) $5 \mathrm{~m}$ long, with a spacing of $1.40 \mathrm{~m}$ between them and $1 \mathrm{~m}$ between plots. The RB867515 genotype was treated as a control since it is a consolidated clone and cultivated throughout Brazil and served as a reference for comparing data obtained from other cultivars.

In November 2015 (5 months after planting [MAP]), February 2016 (8 months after planting) and August 2016 (14 months after planting), the aerial part of the plant was harvested and the dry stem mass was evaluated (MSC), stem potassium content (TKC) and the potassium use efficiency for stem dry matter (EUK).

The sampling area for each evaluation was $2.0 \mathrm{~m}$ from a planting line for each plot, with 15 plants being cut close to the ground and then weighed. After removing the leaves, the central $5 \mathrm{~cm}$ of the stems were washed in running water, rinsed in distilled water, dried in a forced ventilation oven at $65^{\circ} \mathrm{C}$, until reaching constant weight. Then, the dry mass of the samples was ground and subjected to nitro-perchloric digestion, followed by determination of $\mathrm{K}$ by flame photometry.

For the calculation of the efficiency of the use of K (EUK), the stem, which is the commercial product, was used and Equation 1 was used.

\subsection{Statistical Analysis}

$$
\text { EUK }=\frac{\text { MSC }\left(\text { Stem dry matter in } \mathrm{tha}^{-1}\right)}{\text { TKC (Stem K content in dag } \left.\mathrm{kg}^{-1}\right)}
$$

The variables analyzed at 14 MAP (MSC, TKC, EUK) were compared with each other using Pearson's correlations to confirm whether there is a correlation between them and thus verify the possibility of early selection sugarcane cultivars more efficient in the use of $\mathrm{K}$. A scale of values was used to rank the correlation coefficients: Weak correlation: 0.00-0.55; Medium correlation: 0.56-0.70 and Strong correlation: 0.71-1.00.

The stem dry matter (MSC), stem potassium content (TKC) and the potassium use efficiency for stem dry matter (EUK) were subjected to analysis of variance, the means of which were compared by the Tukey test, at $5 \%$ probability. For all variables, the Shapiro-Wilk test was performed to verify whether the data followed a normal distribution. The data were processed using the statistical program R (2018) using the computer software Rbio (Bhering, 2017). The doses effect (quantitative) was studied by regression analysis and the genotype effect (qualitative) was analyzed by $\mathrm{F}$ test at $5 \%$. 


\section{Results}

\subsection{Macroresponds}

The effect of the treatments [Doses (D) and Genotypes (G)] was observed, when these variables were individually considered, for most of the variables studied, in the three evaluation periods, at the level of $5 \%$ probability by the $\mathrm{F}$ test. In the other hand, there was no effect of the interaction between doses and genotypes in all analyzed variables.

It was observed that the increasing doses of $\mathrm{K}$ resulted in positive and increasing performance up to dose 3 (130 $\mathrm{kg} \mathrm{ha}^{-1}$ ), from which a general downward trend was observed. Regarding the genotypes, a different behavior was observed regarding the efficiency of the use of $\mathrm{K}$, indicating more efficient genotypes in the use of this nutrient. Therefore, given the non-interaction between doses versus genotype, the sources of variation were analyzed separately.

\subsection{Effect of Doses}

The production of MSC was influenced by the application of $\mathrm{K}$ in the soil. It was observed that the maximum production of MSC was achieved with the doses of 154,159 and $167 \mathrm{~kg} \mathrm{ha}^{-1}$, at 5, 8 and $14 \mathrm{MAP}$, respectively (Figures 2A, 2B and 2C). Beyond these quantities, there was a drop in the production of MSC. 


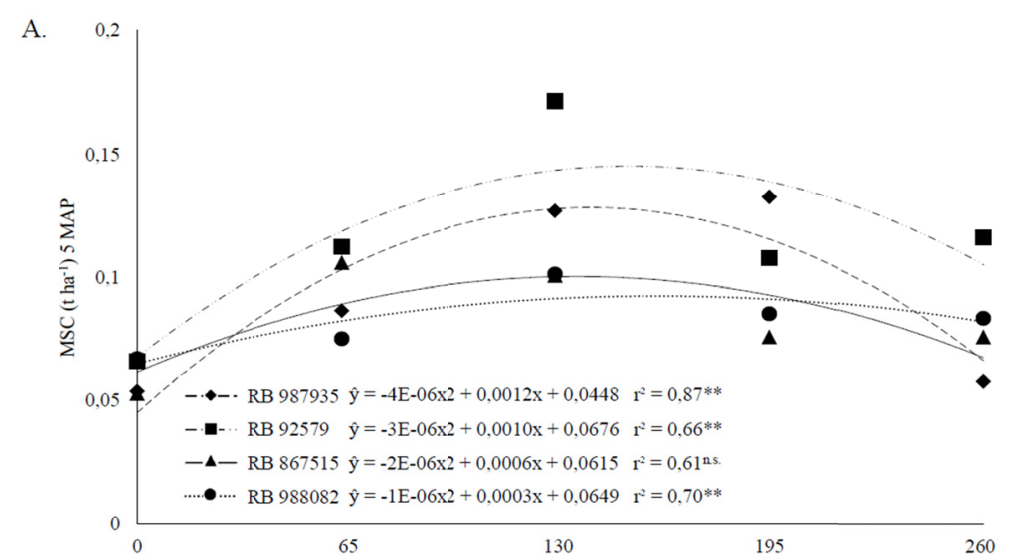

B.
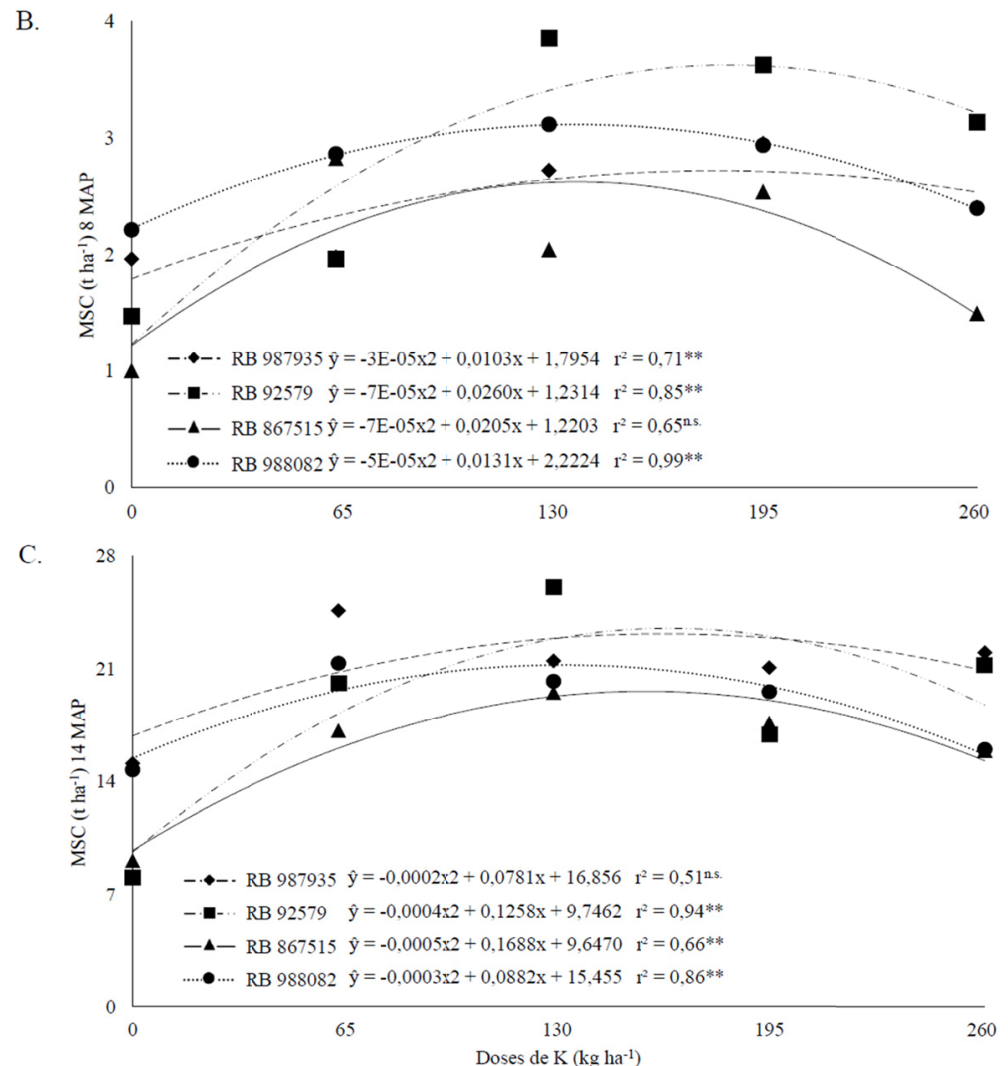

Figure 2. Regression curves for stem dry matter (MSC) of four sugarcane genotypes at five (A), eight (B) and fourteen $(\mathrm{C})$ months after planting as a function of five potassium doses

Note. ${ }^{* *}$ significant at $1 \%$; n.s. not significant by the $\mathrm{F}$ test at $5 \%$.

As for the stem potassium content (TKC), it was observed that, at all times and for all four genotypes, the increase in $\mathrm{K}$ doses provided a linear increase in the content of this nutrient in the stem (Figure 3 ). On the other

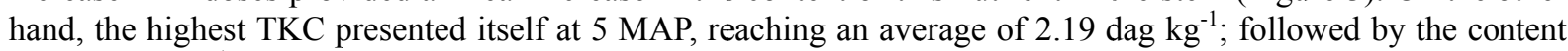
of $1.47 \mathrm{dag} \mathrm{kg}^{-1}$ at $14 \mathrm{MAP}$, while the lowest TKC was reached at $8 \mathrm{MAP}$. The difference between TKC at 5 and 8 MAP can be explained by the rapid growth and accumulation of biomass during these seasons, which decreased the $\mathrm{K}$ content in the stem due to the dilution effect. 
A

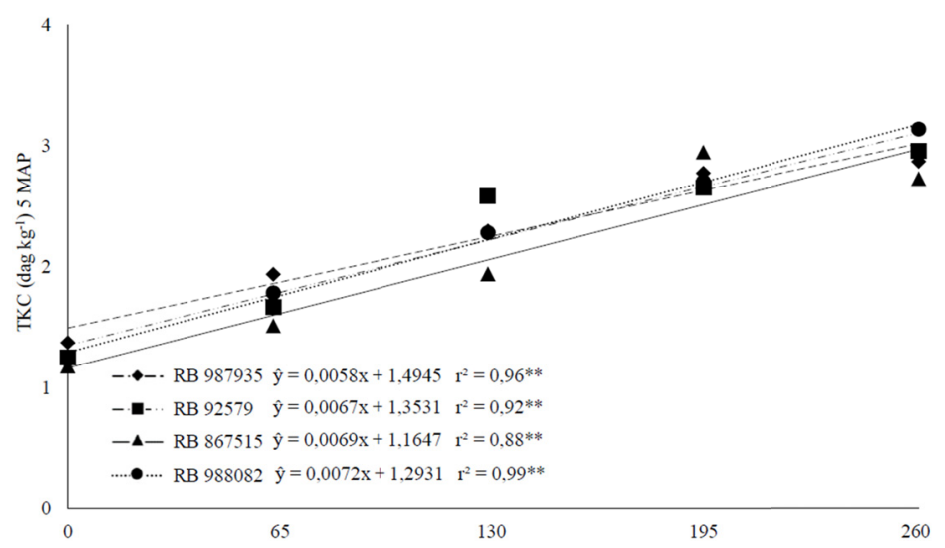

B.

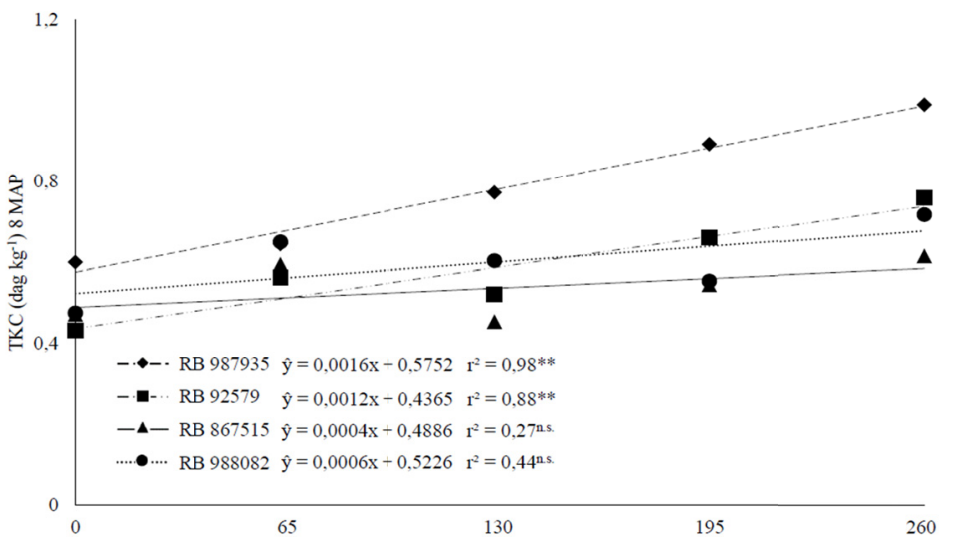

C.

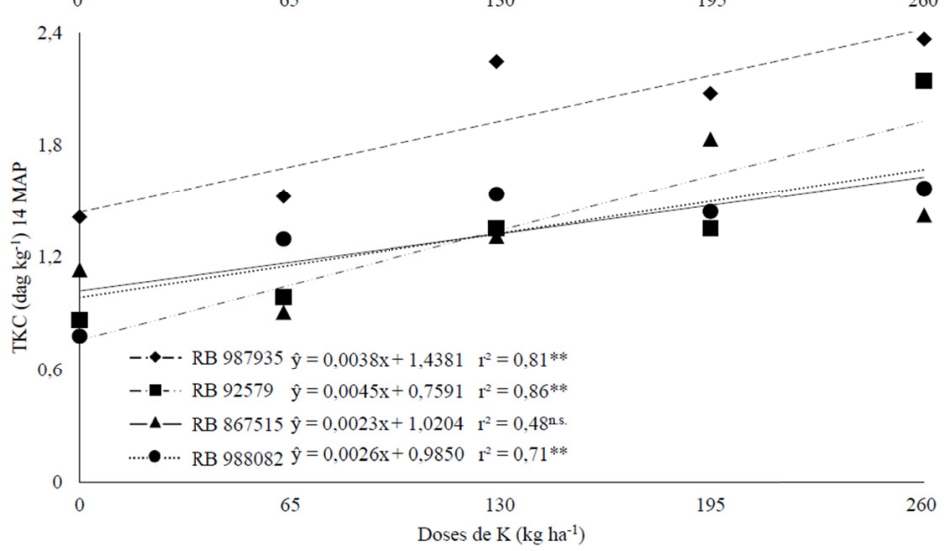

Figure 3. Regression curves for stem potassium content (TKC) of four sugarcane genotypes at five (A), eight (B) and fourteen $(\mathrm{C})$ months after planting as a function of five potassium doses

Note. ${ }^{* *}$ significant at $1 \%$; n.s. not significant by the $\mathrm{F}$ test at $5 \%$.

\subsection{Effect of Genotypes}

As for the genotypes, the RB987935 genotype presented the highest MSC values, while the RB92579 and RB988082 genotypes were intermediate, and the RB867515 presented the lowest performance (Figure 2C).

\subsection{Potassium Use Efficiency for Dry Stem Production}

The stem dry matter was analyzed for TKC and as a criterion in the selection of the most efficient genotypes regarding the use of potassium, since it is from there that its juice is extracted for the subsequent production of ethanol and sugar. The increase in $\mathrm{K}$ content in the stem followed the increase in applied $\mathrm{K}$ doses. The average levels of K at 14 MAP are similar to those found by Bhanuvally, Ramesha, and Yoggeeshappa (2017) and Mariano et al. (2016).

Despite the fact that the $167 \mathrm{~kg} \mathrm{ha}^{-1}$ doses promoted the highest MSC yields at the $14 \mathrm{MAP}$, it was the $107 \mathrm{~kg}$ $\mathrm{ha}^{-1}$ dose that provided the highest EUK results (Figure 4C), because, in addition to providing a performance 
similar to that achieved with $167 \mathrm{~kg} \mathrm{ha}^{-1}$ with only $5 \%$ less production (Figure $2 \mathrm{C}$ ), also presented an average $\mathrm{K}$ content in the stem $26 \%$ lower than dose 3 (Figure 3C), as the EUK is a ratio between the production of biomass and the $\mathrm{K}$ content in the tissue.

The highest EUK was observed in the RB92579 genotype at 5, 8 and 14 MAP, with 6, 21 and 30\%, respectively (Figures 4A, 4B and 4C). These results were caused by the fact that RB92579 genotype showed a TKC lower in $30 \%$ than RB987935 (Figures 3A, 3B and 3C) which was the least efficient, although it was the most productive (Figures 2A, 2B and 2C). EUK values are similar than those reported by Kist, Silveira, Costa, Oliveira and Barbosa (2015) for several sugarcane genotypes.

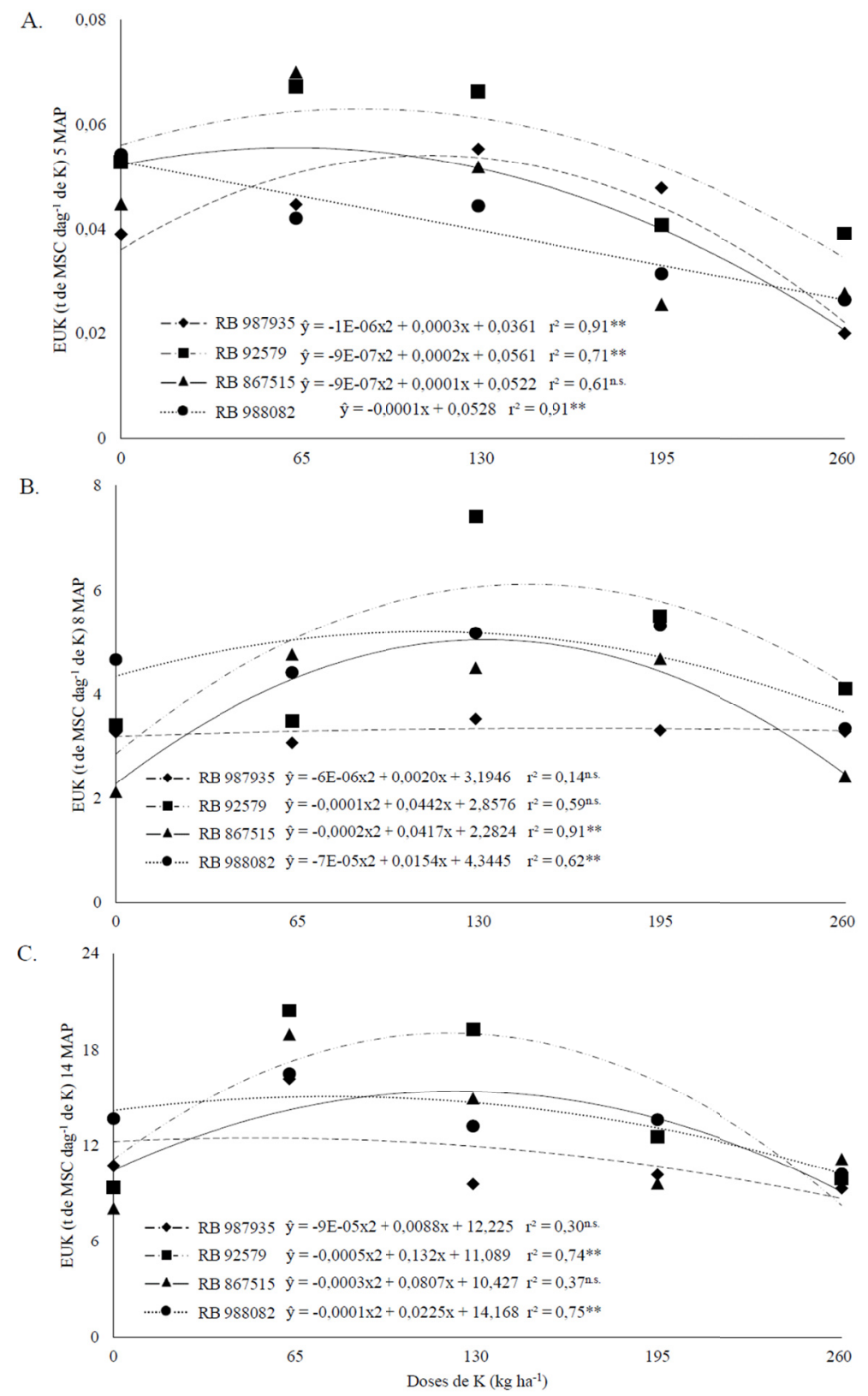

Figure 4. Regression curves for potassium use efficiency (EUK) of four sugarcane genotypes at five (A), eight (B) and fourteen (C) months after planting as a function of five potassium doses

Note. ${ }^{*} *$ significant at $1 \%$; $*$ significant at $5 \%$; n.s. not significant by $\mathrm{F}$ test at $5 \%$. 


\subsection{Correlations}

The chemical analysis, in general, presented a different behavior of the genotypes regarding the behavior in the different evaluated periods, indicating the possibility of identifying genotypes more efficient in the use of $\mathrm{K}$ early. There was a large variation in the potassium doses between the variables analyzed due to the statistical differences between the dose averages, with dose $1\left(0 \mathrm{~kg} \mathrm{ha}^{-1}\right.$ of $\left.\mathrm{K}\right)$ being the one with the highest number of correlations (Table 1). A scale of values was used to rank the correlation coefficients: Weak correlation: 0.00-0.59; Medium correlation: 0.60-0.79 and Strong correlation: 0.80-1.00.

Table 1. Pearson's correlations between the variables of the final evaluation (14 MAP) and the initial evaluations (5 MAP) and ( $8 \mathrm{MAP})$ of sugarcane genotypes as a function of five potassium doses

\begin{tabular}{|c|c|c|c|c|c|c|c|c|c|c|c|c|c|c|c|}
\hline \multirow{2}{*}{ Variables 14 MAP } & \multicolumn{3}{|c|}{ Dose 1} & \multicolumn{3}{|c|}{ Dose 2} & \multicolumn{3}{|c|}{ Dose 3} & \multicolumn{3}{|c|}{ Dose 4} & \multicolumn{3}{|c|}{ Dose 5} \\
\hline & 5 & 8 & 14 & 5 & 8 & 14 & 5 & 8 & 14 & 5 & 8 & 14 & 5 & 8 & 14 \\
\hline & -- & & & & & & & MAP & 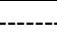 & & & - & - & $\begin{array}{l}---- \\
--1\end{array}$ & --- \\
\hline EUK & 0.1 & 0.6 & 1.0 & 0.0 & 0.0 & 1.0 & -0.2 & 0.5 & 1.0 & -0.1 & 0.3 & 1.0 & 0.2 & -0.3 & 1.0 \\
\hline MSC & 0.4 & 0.6 & 1.0 & -0.1 & -0.2 & 1.0 & 0.3 & 0.2 & 1.0 & 0.0 & 0.0 & 1.0 & 0.0 & 0.3 & 1.0 \\
\hline $\mathrm{TKC}$ & -0.1 & 0.0 & 1.0 & 0.4 & -0.2 & 1.0 & 0.0 & 0.8 & 1.0 & 0.2 & 0.3 & 1.0 & -0.1 & 0.2 & 1.0 \\
\hline
\end{tabular}

Note. Gray-colored data show medium and strong correlations.

\section{Discussion}

The quadratic behavior in the stem dry matter values (Figure 2) due to the increase in the doses of K applied can be explained by the fact that in these doses the maximum need for the crop is reached and $\mathrm{K}$ is the essential element required in greater quantity for the same (Mengel, Kirkby, Kosegarten, \& Appel, 2001).

In this sense, Cavalcante et al. (2015) concluded that, in sugarcane, adequate doses of $\mathrm{K}$ in the soil increase the rate of emergence and vigor of tillers, which leads to greater accumulation of plant dry matter. However, the drop in production from the maximum points may was caused because the plants have a limitation in the selectivity of membranes (Marschner, 1995), thus having an antagonistic effect on the absorption of similar nutrients (case of the exchangeable bases as potassium, calcium and magnesium) physically and chemically. In addition, the negative interactions between nutrients that can be observed due to an excessive concentration caused by an unbalanced supply by the soil (Havlin, Tisdale, Nelson, \& Beaton, 2014).

Thus, when there are high levels of $\mathrm{K}$ in the soil solution, competition can occur in the absorption of other cations such as calcium and magnesium (Rhodes, Miles, \& Hughes, 2018), consequently affecting plant growth.

The behaviors shown in Figure 2 can be explained by the fact that the RB92579 has as main characteristics excellent agricultural productivity, excellent tillering, good closing of the lines, allowing less competition with weeds. In addition, this genotype has better architecture for greater interception of solar radiation, good recovery after periods of drought; it is highly responsive to irrigation and very efficient in the water use (Daros, Oliveira, \& Barbosa, 2015).

The RB92579 genotype showed greater performance over the studied seasons. On the other hand, the low performance of RB867515, in the evaluated seasons, is an unexpected result due to its rapid growth rate; however, the growth of this genotype is negatively affected when cultivated in clay soils (Daros et al., 2015) as the soil of the present study.

The genotypes RB988082 and RB987935 are new materials, recently launched on the market, so it was expected that they would be more productive and efficient in the use of inputs when compared to RB867515, despite the fact that this genotype is consolidated as highly productive throughout the country and in the world.

The genotype RB987935 presented the highest mean values of TKC in all evaluated periods; nonetheless, the other genotypes showed different behaviors, and at 5 MAP, the genotypes RB92579 and RB867515 were shown to be intermediate, while RB988082 obtained the lowest values (Figure 3A). However, at 8 MAP the genotypes RB92579 and RB988082 reached medium levels, while RB867515 showed the lowest values (Figure 3B). Thus, the TKC of RB92579, RB867515 and RB988082 at 14 MAP did not differ (Figure 3C). Kist et al. (2015), who stated that the production of dry matter is not influenced only by the availability and use of nutrients, but by other factors, among them, the yield potential of cultivars, can explain the previous scenario. 
For EUK and MSC from the last evaluation, medium correlations were found at dose 1 to 8 MAP. The TKC showed only a strong correlation in dose 3 at 8 MAP. Thus, the choice of a criterion in the methodology for the early identification of the most efficient genotypes in the use of $\mathrm{K}$, is the result of the time in which it is performed and the dose of $\mathrm{K}$ used; which makes it difficult to standardize the process, obtaining it different EUK values as a function of the $\mathrm{K}$ doses applied to the soil (Figures $2 \mathrm{C}, 3 \mathrm{C}$ and $4 \mathrm{C}$ ). This behavior can be explained by the fact that the efficiency of nutrient use is highly influenced by the amount of fertilizer applied and the soil fertility (Fixen et al., 2014).

The average correlations found in dose 1 at $8 \mathrm{MAP}$ are due to the fact that under low levels of the nutrient in the soil, the genotypes express their real efficiency potential for the use of K. This can be explained by "luxury consumption" by the plant that occurs when the K levels in the soil are well above the plant's needs (Havlin et al., 2014).

Thus, according to Rochester and Constable (2015), the selection of genotypes with higher efficiency in the use of nutrients should occur when soil fertility is low. Wang, Shen, and Liao (2010), mention that those genotypes more efficient in the use of nutrients that manage to maintain adequate levels of productivity even with low concentrations of the nutrient in the tissues when there is a low availability of the nutrient in the soil are very promising.

\section{Conclusions}

It is feasible to use stem dry matter and efficiency in use of $\mathrm{K}$ as a biometric indexes in the selection of sugarcane genotypes efficient in the use of potassium $(\mathrm{K})$ at 8 months of age in the sugarcane plant, when tested under low conditions availability of $\mathrm{K}$ in the soil, that is, without adding fertilizers to the soil. In addition, the viable age to be used for the selection of sugarcane genotypes aiming at the selection of potassium use efficient genotypes is at 8 (eight) months after planting.

\section{Acknowledgements}

The authors thank Brazilian National Council for Scientific and Technological Development (CNPq) and Federal University of Viçosa (UFV) for granting a scholarship to the first, second and third author.

\section{References}

Alvares, C., Stape, J., Sentelhas, P., Gonçalves J., \& Sparovek, G. (2013). Köppen's climate classification map for Brazil. Meteorologische Zeitschrift, 22(6), 711-728. https://doi.org/10.1127/0941-2948/2013/0507

ANDA (Associação Nacional para Difusão de Adubos). (2016). Anuário Estatístico do Setor de Fertilizantes. São Paulo, SP: Associação Nacional para Difusão de Adubos.

Bhanuvally, M., Ramesha, Y., \& Yogeeshappa, H. (2017). Nutrient uptake and millable cane yield of sugarcane as influenced by application of slow releasing nitrogen fertilizers. International Journal of Current Microbiology and Applied Sciences, 6(10), 855-862. https://doi.org/10.20546/ijcmas.2017.610.102

Bhering, L. (2017). Rbio: A tool for biometric and statistical analysis using the R platform. Crop Breeding and Applied Biotechnology, 17, 187-190. https://doi.org/10.1590/1984-70332017v17n2s29

Cavalcante, V., Prado, R., Almeida, J., Silva, T., Flores, R., \& Pancelli, M. (2015). Potassium nutrition in sugar cane ratoons cultured in red latosol with a conservationist system. Journal of Plant Nutrition, 39(3), 315-322. https://doi.org/10.1080/01904167.2015.1009111

CONAB (Companhia Nacional de Abastecimento do Brasil). (2020). Acompanhamento da safra brasileira de cana-de-açúcar-Safra 2019/20 ( $1^{\circ}$ levantamento). Retrieved from https://www.conab.gov.br/info-agro/ safras/cana

Daros, E., Oliveira, R., \& Barbosa, G. (2015). 45 anos de variedades RB de cana-de-açúcar-25 anos de RIDESA (1st ed.). Curitiba, PR: Editora Graciosa.

DNPM (Departamento Nacional de Produção Mineral). (2016). Sumário mineral 2015 (Vol. 35). Brasília, D.C.: Departamento Nacional de Produção Mineral.

Fixen, P., Brentrup, F., Bruulsema, T., Garcia, F., Norton, R., \& Zingore, S. (2014). Nutrient/fertilizer use efficiency: measurement, current situation and trends. In P. Drechsel, P. Heffer, H. Magen, R. Mikkelsen, \& D. Wichelns (Eds.), Managing water and fertilizer for sustainable agriculture intensification. IFA, IWMI, IPNI, IPI. 
Guo, H., White, J., Wang, Z., \& Xing, B. (2018). Nano-enabled fertilizers to control the release and use efficiency of nutrients. Current Opinion in Environmental Science \& Health, 6, 77-83. https://doi.org/ 10.1016/j.coesh.2018.07.009

Havlin, J., Tisdale, S., Nelson, W., \& Beaton, J. (2014). Soil fertility and fertilizers: An introduction to nutrient management (8th ed.). New York, NY: Pearson.

IBGE (Instituto Brasileiro de Geografia e Estatística). (2017). A Geografia da cana-de-açúcar. Rio de Janeiro, RJ: Instituto Brasileiro de Geografia e Estatística.

Kist, V., Silveira, G., Costa, P., Oliveira, M., \& Barbosa, M. (2015). Nutrient use efficiency in sugarcane cultivars. Journal of Agrarian Sciences, 43(2), 117-125. http://doi.org/10.15361/1984-5529.2015v43 n2p117-125

Mariano, E., Leite, J., Megda, M., Ciampitti, I., Vitti, A., Faroni, C., ... Trivelin, P. (2016). Biomass and nutrient content by sugarcane as affected by fertilizer nitrogen sources. Crop Science, 56, 1234-1244. https://doi.org/10.2135/cropsci2015.06.0349

Marschner, H. (1995). Mineral nutrition of higher plants (2nd ed.). New Jersey, NY: Academic Press.

Mengel, K., Kirkby, E. A., Kosegarten, H., \& Appel, T. (2001). Principles of plant nutrition (5th ed.). Dordrecht, NE: Kluwer Academic Publishers.

$\mathrm{R}$ Core Team. (2018). R: A language and environment for statistical computing. R Foundation for Statistical Computing, Vienna, Austria. Retrieved from https://www.R-project.org/

Rhodes, R. Miles N., \& Hughes, J. (2018). Interactions between potassium, calcium and magnesium in sugarcane grown on two contrasting soils in South Africa. Field Crops Research, 223, 1-11. https://doi.org/ 10.1016/j.fcr.2018.01.001

Rochester, I., \& Constable, G. (2015). Improvements in nutrient uptake and nutrient use-efficiency in cotton cultivars released between 1973 and 2006. Field Crops Research, 173, 14-21. https://doi.org/10.1016/ j.fcr.2015.01.001

Shin R. (2014). Strategies for improving potassium use efficiency in plants. Molecules and Cells, 37(8), 575-584. https://doi.org/10.14348\%2Fmolcells.2014.0141

Tomaz, M. A., Silva, S. R., Sakiyama, N. S., \& Martinez, H. E. P. (2003). Eficiência de absorção e uso de cálcio, magnésio e enxofre por mudas enxertadas de Coffea arábica. Revista Brasileira da Ciência do Solo, 27(5), 885-892. https://doi.org/10.1590/S0100-06832003000500013

Wang, X., Shen, J., \& Liao, H. (2010). Acquisition or utilization, which is more critical for enhancing phosphorus efficiency in modern crops? Plant Science, 179(4), 302-306. https://doi.org/10.1016/j.plantsci. 2010.06.007

\section{Copyrights}

Copyright for this article is retained by the author(s), with first publication rights granted to the journal.

This is an open-access article distributed under the terms and conditions of the Creative Commons Attribution license (http://creativecommons.org/licenses/by/4.0/). 